\title{
K fenomenognozii časového vědomí ${ }^{1}$
}

\section{Towards a Phenomenognosy of Time Consciousness}

\author{
Hynek Janoušek \\ Filosofický ústav \\ Akademie věd České Republiky \\ Jilská 1, 11000 Praha 1 \\ $\&$ \\ Filozofická fakulta \\ Univerzita Hradec Králové \\ Rokitanského 62, 50003 Hradec Králové \\ janousek@flu.cas.cz
}

\section{Poznámka překladatele}

Následující text vydal v roce 1930 Oskar Kraus pod názvem Zur Phänomenognosie des Zeitbewußtseins v časopisu Archiv für die gesamte Psychologie, 75, n. 1-2, s. 1-22. Obsahuje výňatky $\mathrm{z}$ korespondence Franze Brentana a pražského profesora KarloFerdinandovy univerzity Antona Martyho z roku 1895 a část Martyho přednášky o Brentanově teorii časového vědomí z téhož roku. Tématem textu je zdůvodnění přechodu od modelu časového vědomí, který pracuje s časovou modifikací předmětů představování, $\mathrm{k}$ modelu, který pracuje s časovou modifikací intencionálního vztahu k předmětu. Ve verzi, která je zde zachycena, jde o přechod ke kontinuální modifikaci aktů souzení, které předmět „kladou“. Čtenáře, který by se zajímal o popis a hlubší zdůvodnění vývoje a povahy Brentanových teorií časového vědomí, bych odkázal na následující texty: Chisholm, R. (1981): „Brentano's Analysis of the Consciousness of Time“. Midwest Studies in Philosophy 6 (1), 3-16, a Chrudzimski, A. (2005): Intentionalität, Zeitbewusstsein und Intersubjektivität, Studien zur Phänomenologie von Brentano bis Ingarden, Ontos, Frankfurt. V češtině pak na Janoušek, H. (2017): „Brentanova teorie času a časového vědomí“. Pro-Fil, 18, no. 1, (v tisku), dostupné online na stránkách časopisu Pro-Fil.

Hynek Janoušek

${ }^{1}$ Tento překlad je výsledkem grantu GAČR P401/11/0371 „Apriorní, syntetické a analytické od středověku po současnou filosofii“, realizovaném na Filosofickém ústavu AV ČR a Filozofické fakultě Univerzity Karlovy. 


\section{I.}

Anton Marty Franzi Brentanovi

Praha, 9. bř̀zna 1895

Drahý příteli a učiteli,

dostal jsem se do časové tísně ohledně jedné kapitoly svých psychologických přednášek. Slíbil jsem, že odpřednáším pozměněnou nauku o čase, ale nyní, když k tomu má neprodleně dojít, vidím, že věc mi není zcela jasná. Myslel jsem, že k ní mám poznámky, které by mě v nejasných bodech přivedly na správnou cestu. Tyto poznámky ale nemohu najít a nevím, jak jinak si rychle poradit, než vás poprosit, zda byste mi nepřispěchal na pomoc a pokud možno mi obratem neodepsal (kapitolu mám totiž probírat již př́ǐší úterý).

1. To, co lze nazývat názorem času, je ve skutečnosti názorem zvláštního modu souzení. Jak se slepou vírou vnějšího názoru, tak s evidencí vnitřního názoru se pojí kontinuum soudů, které nazíraný obsah posuzují a časově odsunují jako stále více a více minulý.

(Poznámka F. Brentana: k bodu 1. „srov. v mém dopise e a f“.)

2. Toto kontinuum vztahů soudů a právě tak i názor času, který se k němu váže, jsou ohraničené. Představa předchozí minulosti a budoucnosti je pojmový útvar vytvořený na základě analogie s daností onoho názoru a soud, že něco je budoucí či že něco bylo včera, není téhož druhu jako onen modus soudu, nýbrž má jen specifickou matérii, která předpokládá jeho reflexi.

(Poznámka F. Brentana: k bodu 2. „srov. v mém dopise g a h“.)

3. Toto kontinuum má jednu dimenzi.

4. Jak se to má s nereálným charakterem časových určení? Zdá se, že nereálnost minulosti neplyne pouze $\mathrm{z}$ intencionality, nebot' vztah $\mathrm{k}$ intencionálnímu je dán i u přítomně existujícího. Přítomné je to, co dává podnět k soudu: že je.

(Poznámka F. Brentana: „srov. v mém dopise m“.)

Obdobně: minulé je to, co dává podnět k onomu specifickému modu souzení. Proč tedy není „minulý“ také pouhým aoristem jako [,,]existující[“]? Pokud se jedná o modifikující predikát, musí to spočívat v něčem jiném.

5. Jak se to má s odpadnutím modifikující abstrakce, o kterém také hovoříte?

(Poznámka F. Brentana: „Nerozumím otázce. Snad se k ní vztahuje h“.) 
Spěchám, předem tisíceré díky.

Váš oddaný
A. Marty

II.

Franz Brentano Antonu Martymu

Vídeň, nedělní večer, březen 1895

Drahý př́teli!

Jelikož ani dnes nejsem ještě zcela při síle, nevím, zda vašemu přání dostatečně vyhovím.

Podle mne uděláte nejlépe, když:

a) předestřete staré hledisko,

b) uplatníte proti němu pochybnosti, zejména, že kontinuum by mělo tvořit cosi heterogenního. Dále, že nereálné by se od reálného lišilo méně, ba dokonce nekonečně méně než nereálné od nereálného.

Poté

c) můžete probrat předešlý názor, který jsem kdysi - nezávisle, avšak ve shodě s Millem - hájil, a ukážete, proč se musel ukázat jako neudržitelný. (Podle tohoto názoru by čas nebyl vůbec kontinuem).

Poté

d) proč jsem ho přesto obnovil, byt' s podstatnými změnami.

e) Tuto obnovu připravil náhled, $\mathrm{k}$ němuž jsem došel zcela nezávisle na těchto úvahách, totiž že každý počitek je spojen s afirmací toho, co je pocit’ováno. (Nezrušitelně, neodpadá ani s poznatkem, že dotyčný fenomén není skutečný. Srovnání s vyšší a nižší žádostivostí. Totéž platí o proterestezi.)

f) Právě tak, jako by člověk mohl přijmout, že předmět proteresteze se kontinuálně modifikuje, lze si také myslet, že předmět se nemění, nýbrž že kontinuální změnu podstupuje afirmace, která se na něj vztahuje.

(Mody afirmace se ukazují být rozmanité, a to zejména rozdíl asertorické o apodiktické [afirmace]. Zde bychom měli pouze jeden druh modů s kontinuálně variujícími species.)

g) Jinak se zprvu nezdá, že by se oproti dřívějšku něco změnilo. Tak, jako byla dříve $\mathrm{v}$ proterestezi ohraničená kontinuální řada předmětů, je v ní nyní ohraničená 
kontinuální řada modů afirmace téhož předmětu. S ní by člověk mohl dále pracovat analogicky.

h) V každém případě zbývá prozkoumat, zda nyní není myslitelné mnohé z toho, co předtím myslitelné nebylo, napr. opravdový modus budoucnosti v očekávání. Musíme se mít na pozoru před tím, abychom zde nechtěli příliš rychle zamítat. Něco takového by bylo zvláště významné pro psychologii zvíratat a pro otázku, zda zviŕrata mohou mít nějakou představu o budoucnosti a něco prríbuzného toužení a usilování. Podle staré teorie se něco takového zdálo podstatně a definitivně vyloučené.

i) Je zjevné, že pochybnosti (b) v nové teorii skutečně nevznikají.

k) ${ }^{2}$ Jak by šlo také poukázat, okolnost, že „sloveso“ (,Zeitwort“) je výrazem afirmace, podporuje názor, že časové diference souvisí s diferencemi afirmace.

1) Zdá se, že i běžný názor je slučitelnější s náhledem, podle nějž je předmět, který je afirmován jako prrítomný či minulý atd., tentýž.

m) Tak, jako [,,]přítomný[“],[,,]existující[“] označují něco, co má být dotyčným způsobem afirmováno, značí také přirozeně i [,,]minulé[“] a [,,]více[“] či [,,]méně minulé["]. Pak si lze samozřejmě vytvořit i obecnější pojmy, jako např. pojem toho, co kdysi minulo; to [,co] je třreba afirmovat způsobem afirmace ze zahrnující skupiny způsobů afirmování.

Takto ve spěchu a zajisté velice neúplně. Doufám však, že pro vás srozumitelně. Kvůli strachu, že můj dopis by mohl dorazit př́liš pozdě, nemohu otálet s jeho odesláním.

III.

$\check{C}$ as

(Z Martyho univerzitní přednášky o Brentanově nauce o času, 1895.)

Je pozoruhodné, že časové rozdíly vyjadřuje řeč kopulou, která je přece znakem přijetí či odmítnutí. O to se asi opírali již starší filosofové, kteří počítali rozdíly času mezi rozdíly soudu.

Již u Aristotela nacházíme náznak v tomto smyslu, není ale jasné, zda považuje čas za rozdíly v matérii nebo ve funkcích soudu.

Tomáš Akvinský se $\mathrm{k}$ tomu také vyjadřuje, dokonce se podle všeho kloní $\mathrm{k}$ založení jednoho z hlavních rozlišení soudů na rozdílech času (komentář k Aristotelově

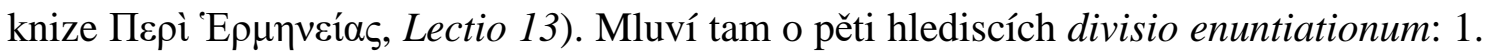

\footnotetext{
${ }^{2} \mathrm{~V}$ originále následuje místo bodu j) ihned bod $\mathrm{k}$ ).
} 
unitas, 2. qualitas, 3. tempus (at' již jde o enuntiatio de praesente, de praeterito, de futuro), 5. materia (de necessitate, impossibilitate, contingentia).

Na základě toho se lze asi domnívat, že Tomáš nepovažoval rozdíl času za pouhý rozdíl materie. V novější době John Stuart Mill v první knize své Logiky zcela jasně konstatoval, že rozdíly času - prrítomnost, minulost a budoucnost - nepovažuje za rozdíly matérie soudu, nýbrž za rozdíly ve způsobu soudového postoje, obdobně jako třeba kvalitu. Domnívá se, že minulé, přítomné a budoucí se netýká predikátu, nýbrž predikování.

Také Brentano, nezávisle na Millovi, hájil takovouto nauku před asi pětadvaceti lety (1868-1870) v přednáškách, jichž jsem byl posluchačem. Když někdo něco afirmuje jako př́itomné či minulé, afirmuje, jak se domníval, tutéž matérii, kdežto způsob afirmace se v obou případech liší. Záhy se však od této nauky odvrátil, zejména proto, že v tomto pojetí by čas netvořil kontinuum. Mill - a tehdy také Brentano - totiž řadil prrítomnost, minulost a budoucnost ke třem diskrétním species rodů soudu. Znovu tedy přesunul čas do matérie představ.

To se zdá být obzvláště patrné u místního pohybu.

Když si představujete tuto tužku, kterou kroužím, nepředstavujete si ji pouze $\mathrm{v}$ jednom bodě (v takovém případě byste si představovali, že se nachází v klidu), nýbrž jako vyskytující se v různých bodech dráhy, avšak ne tak, že by se v nich vyskytovala současně (to byste si představovali tělesný blok o délce proběhlé dráhy), nýbrž spíše byste si ji představovali na různých místech dráhy jako více a více minulou. A sice tak, že je vám specifickým způsobem názorné, že těleso je na nich více a více minulé. Tento názor je záležitostí specifické činnosti fantasie, nikoliv však té činnosti fantasie, která se tak obvykle nazývá, nebot' ta není zcela původní, nýbrž tvoří jen na základě zkušenosti a získaných dispozic. $\mathrm{V}$ představě minulosti máme oproti tomu cosi absolutně nového, co nemá ve zkušenosti vůbec žádnou obdobu. Tím, že si to, co bylo minulé, představuji jako více a více minulé, vstupuje do mého představování absolutně nový moment a Brentano proto tuto činnost fantasie pojmenoval v protikladu k získané asociaci pưvodní asociací.

Domníval se tedy, že díky tzv. ,původní asociaci“, tj. díky specifické vrozené činnosti fantasie na každou počitkovou či vněmovou představu navazuje kontinuální řada fantasijních představ, které reprodukují vnímaný obsah a zároveñ ho mění či modifikují takovým způsobem, že $\mathrm{k}$ němu připojují moment minulosti, a sice vzdálenější a vzdálenější minulosti, takže se jeví takříkajíc časově posunutý.

Tato činnost fantasie, kterou také nazýval proteresteze, je natolik živá, že každý je přesvědčen, že vnímá pohyb a obecně vzato změny, následnosti, že vidí pohyby, slyší melodie. 
Toto kontinuum názorných fantasijních představ je natolik rozsáhlé, že postřehujeme pohyb, který není př́liš pomalý, a právě tak rozpoznáváme melodii jako takovou. Přesto trvání nepřesahuje zlomky vteřin. Celá věta, kterou $\mathrm{k}$ vám pronáším, vám není prrítomná tímto názorným způsobem, nemluvě o celé přednášce, nýbrž po chvilce se opět vzdálí a poté musíte reprodukovat to, co předcházelo, zcela obvyklým způsobem prostřednictvím získané paměti. Myslím, že nejlépe se vám to objasní, když vezmeme v potaz pohyb.

Proč člověk nevidí trávu růst? Protože tento pohyb je př́liš pomalý na to, aby mohl spadat do této specifické, názorné činnosti. Kdyby byla činnost fantasie, která podržuje pocit’ované a časově ho odsouvá, neomezená, museli bychom, pokud bychom dostatečně dlouho přihlíželi, vidět trávu růst.

Další příklad. „Vidíme“, jak se na hodinách pohybuje vteřinová ručička. Proč nevidíme hodinovou ručičku? Očividně proto, že její pohyb je tak pomalý, že již nespadá do oblasti fantasijní činnosti, která nám ho názorně předvádí. Tento krátký kus minulosti je ale celkem naší názorné představy času a mimo něj si představu vzdálenější minulosti tvoříme pouze pojmově a právě tak - na základě analogie k „dříve“ a „později“ danými v názoru - si tvoříme i pojem budoucnosti. Má se to zde podobně jako v př́padě názoru prostoru. Názorně je nám toho dáno jen velice málo. Naše vizuální pole je neobyčejně úzké, a přesto tento malý kapitál umíme nesmírně rozhojnit. Prostory pojmově rozšiřujeme do nekonečna. A tak vycházíme z malého, názorného kusu názoru času, který fantasie nechává v každém okamžiku opět odejít, tvoříme si pojmy nezměrných časů, hovoříme o miliónech let.

Celek těchto časových určení, těch, která jsou nám názorně dána, a těch, která si k nim pojmově konstruujeme, je analogický k nekonečné linii, tj. species se proměňují v jedné dimenzi, a sice potencionálně do nekonečna. Jinými slovy: neexistují přirozeně poslední species, nýbrž to, jaké konkrétní hranice má náš názor času, je záležitostí naší specifické organizace a trvání časového názoru by se mohlo u různých individuí a různých smyslů lišit.

Jelikož časová species tvoří kontinuum, takže je jich vždy spolu dáno mnoho, ba dokonce nekonečné množství, jsou s nimi vždy v názoru spoludány i relace a to podpořilo známý klam, totiž že čas jako takový je čímsi pouze relativním, např. Lebniz se proto domníval, že čas je následnost. Ve skutečnosti není samozřejmě čas následností, nýbrž následnost předpokládá čas. Dříve nebo později jsou časové relace, které předpokládají absolutní časová určení, podobně, jako tomu je v případě místa.

Přece jen je však něco, co v případě místa nefiguruje! Časová určení, která se prostřednictvím proteresteze přidružují jsou modifikující predikáty, nikoliv predikáty determinujicí. 
Objasnit to lze jen na př́kladech. Červeň, která je zde, a modř, která je tam, jsou skutečnou modří a červení. Predikáty ,zde“ a "tam“ jsou determinující. Minulý tón není oproti tomu skutečný tón, včerejší či budoucí déšt' není skutečný déšt'. Nikdo v něm nezmokne. „Minulý“ a „budoucí“ jsou modifikující predikáty, právě tak predikáty „namalovaný“, „představovaný“, „milovaný“, „,nenáviděný, „,chtěný“ apod.

Tím to však nekončí. Všechny tyto predikáty proměňuji to, co je reálné, $v$ nereálné. Představovaný ,zámek“ nejenže není zámkem, nýbrž není vůbec ničím skutečným. Právě tak minulé jako takové, budoucí jako takové.

... Právě tato zvláštnost, totiž že to, co je minulé a budoucí, není reálné, však vyvolává vážnou pochybnost ohledně právě vyložené nauky, že časové rozdíly jsou záležitostí představovaných obsahů. Pokud je čas, právě tak jako prostor, kontinuum, pak zde musí kontinuum tvořit zcela heterogenní složky, dokonce tak heterogenní jako je reálno a nereálno - a to je nanejvýš problematické. Pak totiž musí př́tomná červeň kontinuálně souviset s minulou červení. A pokud je sjednocena v kontinuu, pak se, ačkoliv prvá je reálná a druhá nereálná, odlišuje méně než nereálná od nereálné, dokonce infinitesimálně, tj. nekonečně méně! Jak by něco takového bylo možné? Barvy a tóny přece netvoří kontinuum. Proč ne? Protože jsou různého druhu. Přesto si jsou přeci jen bližší v té míře, nakolik jsou obě čímsi reálným. Minulé a budoucí oproti tomu odděluje mnohem větší propast než tóny a barvy.

Zde narážíme na velký problém. (Ze starších skript můžete zjistit, že i v době, kdy jsem zastával starší názor, jsem zdůrazňoval jeho obzvláštní závažnost a záhadnost.)

Abychom tento problém mohli odstranit z cesty, zdá se, že se přeci jen budeme muset opět vrátit ke starému názoru, že čas není záležitostí představovaného obsahu, nýbrž modu soudu, a také Brentano se k němu nyní kloní, byt' ve výrazně změněné podobě. Obnovení tohoto stanoviska připravilo přesvědčení, jež bylo získáno zcela nezávisle na něm, a sice že každý počitek je pưvodně a nezrušitelně spojen s uznáním pocitovaného.

Již jsem se častěji zmínil o tom, že dítě instinktivně a na základě vrozeného sklonu považuje za pravdivé vše, co se mu jeví. Přihlédneme-li bliže, ukazuje se, že tuto instinktivní víru nelze od počitku vi̊bec oddělit.

Tato smyslová víra, mohu-li to tak vyjádřit, na níž se zakládá i tato bezprostřední víra ve vnější svět, je sice vyšším stupněm poznání takř́ikajíc suspendována, nelze ji však vykořenit. Nejde o superponovaný akt, nebot' k pojmu superponovaného aktu patří jednostranná oddělitelnost. Spíše je tomu tak, že počitek je akt, který obsahuje dvě neoddělitelné části, a sice názor fyzického fenoménu a jeho asertorické uznání.

Proti tomu lze namítnout, že se od této smyslové víry, která je tak patrná u dětí a v př́ípadech smyslových klamů, můžeme přece oprostit. Zcela nepochybně se to tak má mít s fyzikem, filosofem, fyziologem, a do jisté míry již s obyčejným člověkem. Na to 
je třeba odpovědět takto: v případě tzv. oproštění od smyslové víry nacházíme ve skutečnosti dva soudy. Na základě rozumové úvahy vzniká soud rozumu, náhled, určitý poznatek. Onen instinktivní soud však přitom trvá. Trvá a prosazuje se navzdory opačnému poznatku, že fenomén není skutečný. (Již u Aristotela se k tomu nachází poukaz na známý smyslový klam s kuličkami mezi překříženými prsty. Stokrát si můžete říkat, že jde pouze o jednu kuličku. Smyslový klam, že jsou dvě, přesto nadále trvá.) I Helmholtz ohledně optických klamů opakovaně zdůrazňoval, že trvají i poté, co jsme nahlédli omyl a tudíž rozumově soudíme opačně. Obecně známým případem jsou perspektivní klamy.

Tento protiklad nižšího a vyššího souzení má svou obdobu v oblasti emočněvolních činností. I mezi nižší a vyšší touhou existuje očividný konflikt. Velmi často totéž zároveň milujeme a nenávidíme, smyslově milujeme slepě, nenávidíme z vyšších, etických ohledů. Když asketa nebo kdokoliv z nás za jistých okolností potírá určité smyslové touhy a volí opak, protože se z etických důvodů drží zpět, pomíjí snad smyslová touha? Nikoliv, nadále trvá. Odtud také nauka moralistů, že tzv. motus primoprimi voluntatis není hříšný, protože ho neovládáme, protože je dokonce nevykořenitelný.

V tomtéž vědomí se proto může nalézat protikladný nižší a vyšší soud, a domnívám se, že mohu s jistotou trvat na tom, že ke každému smyslovému názoru patří jakožto část téhož fundamentálního aktu nedílně a nezadržitelně víra v jeho obsah.

Takováto víra nepatří pouze $\mathrm{k}$ počitku, nýbrž také $\mathrm{k}$ proterestezi. Tímto smyslovým způsobem se naše víra netýká jen současného tónu, ale také tónu bezprostředně předcházejího. I zde akt názoru zároveň obsahuje afirmující soud. Namísto toho, abychom v kontinuální modifikaci mysleli předmět proteresteze, nabízí se přeložit tuto modifikaci do afirmace, která se ho týká, zatímco předmět se nemění. Předmět proteresteze je tentýž jako předmět počitku, je však spojen s modifikujícím způsobem afirmování. Stále např. nazíráme a afirmujeme červeň, tato afirmace ale podléhá kontinuální změně, a je tím, co předmět takříkajíc časově odsunuje a co tvoří zdroj našeho pojmu času.

Víme přece již, že existují rozmanité způsoby afirmace, např. evidentní afirmace jako zvláštní způsob oproti slepé, motivovaná jako zvláštní způsob oproti nemotivované. Právě tak je i časová afirmace zvláštní modifikací, až na to, že přitom máme dán druh modů afirmování s kontinuálně variujícími species. Mody afirmování zde tvoří jednodimenzionální kontinuum. Toto kontinuum je celkem vzato ohraničené, jak jsem již říkali na základě předchozího názoru, a sice relativně úzce ohraničené.

Podle předchozího názoru jsme měli omezenou kontinuální řadu předmětů, které jsou vždy jinak modifikovány, zde máme kontinuální řadu modů afirmace téhož předmětu. 
Přirozeně i podle nového názoru nadále platí, že čas nelze identifikovat se vztahy předcházení a následování, nýbrž že tyto vztahy se zakládají na absolutních určeních. Nemění se také, že omezení nespočívá v povaze časových species, naopak, pojmově lze kontinuum donekonečna konstruovat, takže představuje analogon nekonečné př́ímky.

Vidíte tedy, že řada bodů zůstává podle nového i starého názoru beze změn. Jeden však odpadá, a sice potíž, která činila starší názor tolik problematickým, totiž že dopouštěl, aby reálné a nereálné tvořily kontinuum. Nyní na sebe totiž kontinuálně navazují mody afirmování, a ty jsou všechny reálné. Předmět oproti tomu trvá beze změn, minulá červeň nenavazuje na přítomnou červeň, nýbrž červeň trvá, aniž by se měnila.

Pokud se někdo zeptá: Existuje nyní vůbec ještě názor času a co to vlastně je? Odpovíme: Tento titul si nezaslouží názor fyzických fenoménů, nýbrž názor psychického fenoménu, resp. kontinua psychických fenoménů, kontinuálně variující řady modů soudu - a zde je třeba hledat zdroje všech časových pojmů. Na základě tohoto názoru ohraničeného kontinua specifických modů afirmace si totiž posléze můžeme vytvořit pojmy vzdálenější minulosti a pojmy budoucnosti, jejíž názor ve vlastním smyslu nemáme.

Nasnadě je ještě jedna otázka. Časová určení přece připisujeme věcem. Mluvíme o „včerejším dešti“, o „dnešním obědě“, o „,budoucí zkoušce“ a to přece nejsou mody afirmování, nýbrž věci zcela jiného druhu.

Odpověd’ zní: Tyto predikáty označují vztahy k možným soudů specifického modu afirmování.

Připomeňte si pojem existence! Jak jsem se vyjádřili k tomu, co je existující? Existující je to, co má být afirmováno. Právě tak jako prrítomně existující znamená to, co má být tímto způsobem afirmováno, znamená minulé a dříve či později minulé to, co má být tímto způsobem modifikovaně afirmováno, a tyto predikáty nejsou reálné.

Samozřejmě, že pak si lze vytvořit obecné pojmy, jako například „to, co kdysi minulo“. A to neznamená nic jiného než to,co je třeba afirmovat nějakým modem afirmace ze zahrnující skupiny způsobů afirmování. Millova a dříve také Brentanova chyba spočívala v domněnce, že „minulé“ je jednou species a „budoucí“ jinou species. Čas by pak netvořil kontinuum. To, co nazýváme minulé, je pouze obecnější jméno pro zahrnující skupinu species, které infinitesimálně variují, ale každý se od všech ostatních liší.

Nic jistějšího podle mne o temném pojmu času - nebot' ten určitě patří k těm nejtemnějším - říci nemůžeme. 